\title{
Energy efficiency in the building materials industry. Case study: Brick manufacturing in Romania
}

\author{
Cristian Gheorghiu ${ }^{1}$, Mircea Scripcariu ${ }^{1}$, Miruna Gheorghiu ${ }^{2 *}$, and Alexandra Gabriela \\ Dobrica $^{1}$ \\ ${ }^{1}$ University Politehnica of Bucharest, Energy Production and Use Department, 313 Splaiul \\ Independentei, Bucharest, Romania \\ ${ }^{2}$ ELSACO ESCO L.L.C.,500 Mihai Bravu, Bucharest, Romania
}

\begin{abstract}
In this paper an overview of the construction materials industry, from an embedded energy point of view will be presented. A case study for four brick factories in Romania will also analyzed. The Energy Performance Indicators (EnPI) of each factory will be evaluated and compared with the global reference values and the most technically and economically feasible Energy Performance Improvement Actions (EPIAs) will be presented. The replicability of these EPIA's in different materials manufacturing industries will be also analyzed.
\end{abstract}

\section{Introduction}

As the European Construction Sector Observatory (ECSO) has shown in its latest report, even though the building construction market in Romania has grown by more than $173.4 \%$ from 2010 to 2018 [1], Romania still has some of the largest overcrowding (46.3\%) and severe house depravation (16.1\%) rates in the European Union [2]. The construction materials market growth continued throughout 2020, despite the COVID-19 pandemic and is expected to reach 1.5 trillion $\$$ by the end of 2027 [3] and is currently responsible for 6\% of the global share of energy use, respectively $11 \%$ of the Greenhouse Gases Emissions (GHG), of the entire building sector. Considering that the European Union's latest Directives regarding energy efficiency [4] and environmental impact reduction [5] increased the target for energy efficiency and set a target for carbon neutrality for 2050, the construction material industry has a new set of challenges which must be addressed. The most relevant challenges that need to be addressed in order to ensure a circular economy in the construction material industry are, as [6] shows: stimulating demand, training, innovation respectively energy efficiency and climate change. This paper analyzes the construction material manufacturing industry in Romania with emphasis on the brick manufacturing industry. As demonstrated by [7] and [8], the brick manufacturing sector is

${ }^{*}$ Corresponding author: miruna.gheorghiu.c@gmail.com 
continuously trying to improve the technological process thus improving both the final product quality and the EnPI.

The main objective of the paper is to analyze the technic and economic viability of implementing large scale Energy Performance Improvement Actions (EPIAs) in brick factories and to evaluate the potential of environmental impact reduction. The second objective of the research is to identify the main static and variable factors that influence the EnPI and can be used to normalize the aforementioned indicators in order to properly develop a long-term energy performance analysis methodology.

Four Brick Factories (BF), owned and operated by the same company, will be analyzed from an energy performance and environmental impact point of view. Various EPIAs will be identified, presented, and analyzed from a technical and economic point of view to determine the Environmental Impact Reduction (EIR) potential of this building material manufacturing sub-sector.

\section{Energy Boundary Description}

In all four Brick Factories analyzed, electricity and natural gas are the main forms of energy used. Figure 1 shows the share of each form of energy of the total equivalent energy consumption.
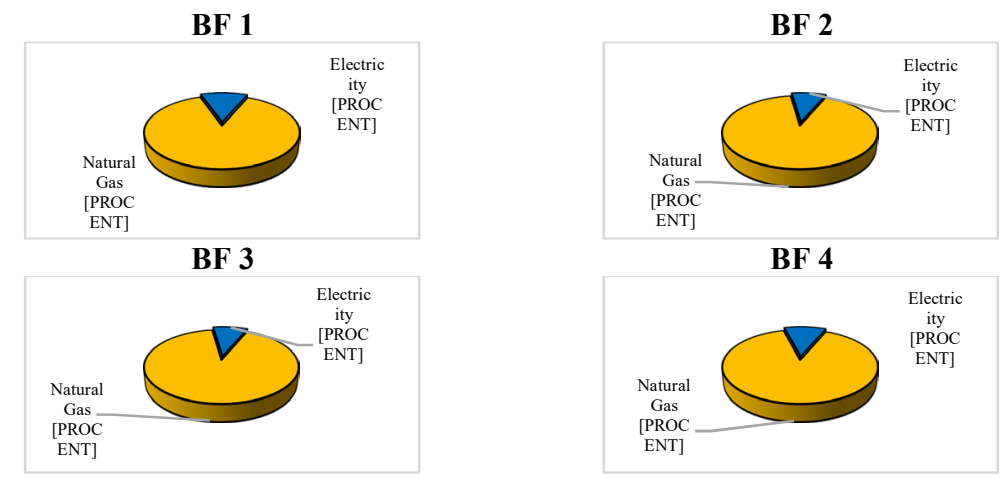

Fig. 1. The share of each form of energy of the total equivalent energy consumption

As it can be observed, in the brick production process natural gas has a higher share compared to electricity, by a factor of nine. Natural gas is used as fuel for the steam boiler, for the burners in the drying chambers and by the brick heat treatment oven, which ensures the ripening process and is the main natural gas end-user. Electricity is used by the industrial robots, air ventilation systems, lighting systems and the IT\&C system.

In order to determine the Energy Performance Indicators (EnPIs), the Environmental Impact Indicators and to determine the energy baseline for the four analyzed Energy Boundaries, a brief energy use comparison is presented in Table 1.

Based on the data presented in Table 1, it can be observed that the natural gas and electricity use are directly proportional with the annual brick production in all four case study sites. In order to evaluate the energy performance of each site, to compare the results and to quantify the impact of the various proposed EPIAs, an in-depth analysis of specific EnPIs has to be performed. 
Table 1. Natural Gas and Electricity consumption for each Brick Factory

\begin{tabular}{|c|c|c|c|}
\hline Brick Factory & $\begin{array}{c}\text { Natural Gas Use } \\
\text { [MWh/year] }\end{array}$ & $\begin{array}{c}\text { Electricity Use } \\
\text { [MWh/year] }\end{array}$ & $\begin{array}{c}\text { Annual Production } \\
\text { [tons/year] }\end{array}$ \\
\hline BF 1 & 80,216 & 10,713 & 237,626 \\
\hline BF 2 & 56,631 & 5,397 & 196,947 \\
\hline BF 3 & 70,523 & 7,281 & 234,516 \\
\hline BF 4 & 53,820 & 6,320 & 116,096 \\
\hline
\end{tabular}

\subsection{Energy Performance Analysis}

To analyze and understand the energy performance related to energy use, it is necessary to identify the relevant Energy Performance Indicators.

Energy Intensity (EI) was selected as a global EnPI as it is also the most commonly used indicator in Energy Audits, and it is also the global EnPI that EU Member States have to annually report to the European Commission. EI was determined by using equation (1):

$$
E I=\frac{W_{e q}}{P V}\left[\frac{t . o . e .}{E U R \cdot 10^{3}}\right]
$$

where $E E$ [t.o.e./year] is the annual equivalent energy use of the energy boundary, expressed in tons of oil equivalent (t.o.e.) and $P V$ [thousand EURs/year] is the yearly production income.

In order to evaluate the Specific Electricity $\left(W_{e l}^{s p}\right)$ and Natural Gas $\left(W_{n g}^{s p}\right)$ use with regard to the annual brick production, thus determining the electricity and natural gas baselines, equations (2) and (3) were used.

$$
W_{e l}^{s p}=\frac{W^{e}}{P}\left[\frac{M W h}{t o n}\right]
$$

where $W^{e}[\mathrm{MWh} / \mathrm{year}]$ is the annual electricity use of the energy boundary, expressed in $\mathrm{MWh} /$ year and $P[$ tons/year $]$ is the yearly production of the $\mathrm{BF}$.

$$
W_{n g}^{s p}=\frac{W^{n g}}{P}\left[\frac{M W h}{\text { ton }}\right]
$$

where $W^{e}$ [MWh/year] is the annual natural gas use of the energy boundary, expressed in $\mathrm{MWh} /$ year and $P[$ tons/year] is the yearly production of the BF.

To get an overall view of the energy performance of each site, the Specific Equivalent Energy $\left(W_{e q}^{s p}\right)$ use was determined with equation (4).

$$
W_{e q}^{s p}=\frac{W^{e q}}{P}\left[\frac{\text { t.o.e. }}{\text { ton }}\right]
$$

where $W^{e q}$ [t.o.e./year] is the annual equivalent energy use of the energy boundary, expressed in tons of oil equivalent (t.o.e.) and $P$ [tons/year] is the yearly production of the BF.

The results of the unadjusted Energy Performance analysis will be presented in Table 2 and Figure 2.

Table 2. Energy Performance analysis results - EnPI baseline

\begin{tabular}{|c|c|c|c|c|}
\hline $\begin{array}{c}\text { Brick } \\
\text { Factory }\end{array}$ & EI [t.o.e./EUR·10 $\left.{ }^{3}\right]$ & $\mathbf{W}_{\text {el }}^{\text {sp }}[\mathbf{M W h} / \mathbf{t o n}]$ & $\mathbf{W}_{\text {ng }}{ }^{\text {sp }}[\mathbf{M W h} / \mathbf{t o n}]$ & $\mathbf{W}_{\text {eq }}{ }^{\text {sp }}[$ t.o.e./ton] \\
\hline BF 1 & 0.6616 & 0.0451 & 0.3376 & 0.0329 \\
\hline BF 2 & 0.5072 & 0.0274 & 0.2875 & 0.0271 \\
\hline BF 3 & 0.5892 & 0.0310 & 0.3007 & 0.0285 \\
\hline BF 4 & 0.9648 & 0.0544 & 0.4620 & 0.0444 \\
\hline
\end{tabular}




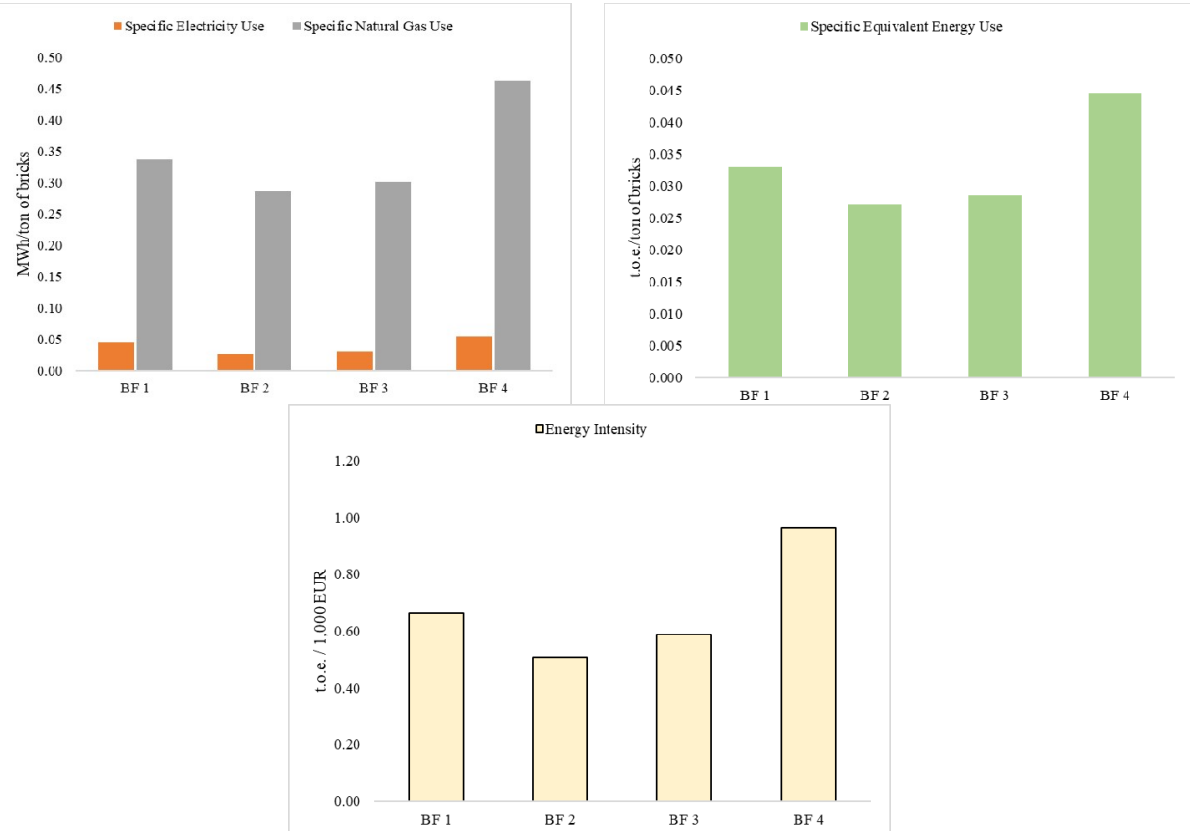

Fig. 2. EnPI Baseline - Comparison between the four factories

It can be observed that BF 1 and BF 4 have the highest values for all the analyzed EnPI, which leads to the conclusion that these two energy boundaries are the least energy efficient. The most energy efficient production site is BF 2. It obtained an Energy Intensity of only 0.5072 t.o.e./thousand EUR, representing only $52 \%$ of the EI registered by BF 4 .

This difference can be explained by the fact that BF 4 was acquired by the company less than a year ago. The factory was still in the process of implementing the various good practice operational guidelines that the new owner already developed and successfully tested in the other production sites. In order to compare the energy performance of the analyzed energy boundaries with the world average, an industry specific EnPI has to be used. The specific equivalent energy use for each thousand bricks was determined by using equation (5):

$$
W_{e q}^{\text {sp, brick }}=W_{e q} \cdot 41.868 \cdot \frac{P}{B W} \cdot 10^{3}\left[\frac{G J}{10^{3} \text { bricks }}\right]
$$

where BW is the average brick weight of $15.5 \mathrm{~kg}$ for the four analyzed factories. The average value had to be considered because each factory produces at least 3 different types of bricks. As it can be observed from Table 3, some of the analyzed factories have better $W_{e q}^{\text {sp,brick }}$ values than the global average whilst others fall behind. This EnPI can be used by the Management of the owner-company to prioritize the EPIAs implementation in BF 4.

Table 3. EnPI comparison

\begin{tabular}{|c|c|c|c|}
\hline \multirow{2}{*}{ Factory } & \multicolumn{2}{|c|}{ Production } & \multirow{2}{*}{$\begin{array}{c}\text { Specific Energy use } \\
\text { [t.o.e./10 }{ }^{3} \text { bricks] }\end{array}$} \\
\hline & [tons] & [bricks] & \\
\hline BF 1 & $237,626.44$ & $15,330,739$ & 21.36 \\
\hline BF 2 & $196,947.18$ & $12,706,270$ & 17.58 \\
\hline BF 3 & $234,516.22$ & $15,130,079$ & 18.52 \\
\hline $\mathrm{BF} 4$ & $116,095.88$ & $7,490,057$ & 28.91 \\
\hline \multicolumn{3}{|c|}{ Clay brick average specific energy use in Canada [9] } & 22.046 \\
\hline \multicolumn{3}{|c|}{ Clay brick average specific energy use in S.U.A. [10] } & 9.3 \\
\hline \multicolumn{3}{|c|}{ Clay brick average specific energy use in Brazil [11] } & 55.211 \\
\hline
\end{tabular}




\subsection{Environmental Impact Analysis}

Reducing the environmental impact is the most important national, European and international energy efficiency target. The Environmental Impact Indicators were calculated according to equations (5), (6) and (7).

In order to determine the annual quantity of equivalent greenhouse gases emission the following conversion factors for natural gas and electricity were used: $202 \mathrm{gCO}_{2, \mathrm{eq}} / \mathrm{kWh}$ $\left(\mathrm{f}_{\text {ng }}\right)$ and $345 \mathrm{gCO}_{2, \mathrm{eq}} / \mathrm{kWh}\left(\mathrm{f}_{\mathrm{el}}\right)[12]$.

The unadjusted overall equivalent $\mathrm{CO}_{2}$ emissions $\left(\mathrm{A}_{\mathrm{CO} 2}\right)$ were determined, for each site, and will serve as an environmental impact indicator baseline.

$$
A_{\mathrm{CO} 2}=W^{n g} \cdot f_{n g}+W^{e l} \cdot f_{e l}\left[\frac{\text { tons } \mathrm{CO}_{2}}{\text { year }}\right]
$$

As $\mathrm{A}_{\mathrm{CO} 2}$ cannot be used to compare the four production sites, specific environmental impact indicators have to be used. Thus, the specific $\mathrm{CO}_{2}$ emissions reported to the production of each site was determined by using equation (6).

$$
\mathrm{CO}_{2, e q}^{s p}=\frac{A_{\mathrm{CO} 2}}{P}\left[\frac{\text { tons } \mathrm{CO}_{2}}{\text { tons of brick }}\right]
$$

Furthermore, a global environmental impact indicator was proposed in this paper. In order to properly quantify the environmental impact from an economic point of view, an analysis regarding the weight of $\mathrm{CO}_{2}$ emissions in the global economic productivity was developed. The Environmental Impact Intensity (EII) was determined by using equation (7) and can be used to compare various industries.

$$
E I I=\frac{A_{C O 2}}{P V}\left[\frac{\text { tons } \mathrm{CO}_{2}}{E U R \cdot 10^{3}}\right]
$$

\begin{tabular}{|c|c|c|c|}
\hline Brick Factory & $\begin{array}{c}\mathrm{A}_{\mathrm{CO} 2} \\
\text { [tons } \mathrm{CO}_{2} / \text { year] }\end{array}$ & $\begin{array}{c}\mathrm{CO}_{2, \text { eq }}{ }^{\text {sp }} \\
\text { [tons } \mathrm{CO}_{2} / \text { ton of brick] }\end{array}$ & $\begin{array}{c}\text { EII } \\
{\left[\text { tons } \mathrm{CO}_{2} / \mathrm{EUR} \cdot \mathbf{1 0}^{3}\right]}\end{array}$ \\
\hline BF 1 & $19,899.93$ & 0.0837 & 0.3450 \\
\hline BF 2 & $13,301.75$ & 0.0675 & 0.2592 \\
\hline BF 3 & $16,757.63$ & 0.0715 & 0.3024 \\
\hline BF 4 & $13,016.11$ & 0.1121 & 0.4990 \\
\hline
\end{tabular}

The unadjusted results of Environmental Impact Analysis will be presented in Table 4.

Table 4. Energy Performance analysis results - EnPI baseline

As expected, $\mathrm{BF} 4$ has the worst EII value of 0.5 tons of $\mathrm{CO}_{2} /$ ton of brick. This means that for every ton of brick produced, $\mathrm{BF} 4$ has to pay for $0.5 \mathrm{CO}_{2}$ certificates. In the context of the European Union's fourth phase of the EU-ETS mechanism [13], if the EII values will not be improved, the overall economic efficiency of the analyzed energy boundaries will decrease over time by a factor of $7 \%$. The weight of $\mathrm{CO}_{2}$ certificates in the overall operational expenditures (OPEX) is, as of 2021, approximatively $5.45 \%$. When the $\mathrm{CO}_{2}$ certificates will reach the maximum price of $100 \mathrm{EUR} /$ certificate, the weight will increase to $13.63 \%$. It is thus obvious that the owner company has to prioritize the implementation of EPIAs in order to maximize the potential for sustainability and decarbonization.

\subsection{Static and variable factors}

Over time the principle of brick production never changed, just the technology of production. Thus, the brick factories are more efficient, and the quality of products have been improved. A better knowledge of raw materials and their properties, of the equipment uses, of the factors that influence the production, the energy consumption and quality of products contribute to more advanced concepts for brick factories and a better quality of brick production [14]. 
There are six major ingredients for brick production. Silica (Sand) and Alumina (Clay), these two are the most prominent ingredients in brick clay.

The clay used must have certain properties and the most important are plasticity, that allows it to shape and homogenize with water, and calorific value according which, in the process of ripening the brick, more or less natural gas is consumed.

Because each factory is built near a clay quarry, there is no possibility to change the clay used in the production process. But a lot of tests have been done with different types of clay, and the amount of natural gas required for ripening was lower if the calorific value of the clay was lower and vice versa. $\mathrm{CO}_{2}$ emissions varied similarly to natural gas consumption. Other static and variable factors that were identified during this case study are presented in Table 5 .

Table 5. Factors influencing energy use

\begin{tabular}{|c|c|c|c|c|}
\hline Factor & Type & Influences & $\begin{array}{c}\text { Can be } \\
\text { optimized? }\end{array}$ & How? \\
\hline $\begin{array}{c}\text { Sand } \\
\text { granulation }\end{array}$ & Variable & $\begin{array}{c}\text { Drying process duration } \\
\text { / brick quality }\end{array}$ & Yes & $\begin{array}{c}\text { Ensuring a 0.2 mm } \\
\text { granulation }\end{array}$ \\
\hline $\begin{array}{c}\text { Sawdust } \\
\text { humidity }\end{array}$ & Variable & Sifting process duration & Yes & $\begin{array}{c}\text { Stored in controlled } \\
\text { atmosphere environment }\end{array}$ \\
\hline $\begin{array}{c}\text { Outdoor } \\
\text { temperature }\end{array}$ & Variable & Natural gas consumption & Yes & $\begin{array}{c}\text { Optimizing heat flow in the } \\
\text { heat treatment oven }\end{array}$ \\
\hline $\begin{array}{c}\text { Type of drying } \\
\text { system }\end{array}$ & Static & Drying process duration & Yes & $\begin{array}{c}\text { Replacing drying chambers } \\
\text { with drying tunnels }\end{array}$ \\
\hline
\end{tabular}

\section{Energy Performance Improvement Actions}

\subsection{Improving the energy monitoring system}

In order to maximize the efficiency of identifying the relevant EPIA's, the implementation of an advanced energy monitoring system in each of the analyzed energy boundaries is mandatory. As [15] shows, by developing a system in accordance with [16] an overall EnPI improvement of up to $3 \%$ can be achieved with minimal investments and minor operational improvement actions. Based on the technological process diagram, a monitoring system architecture was proposed. The system will lead to an accurate measurement procedure for: global electricity use, individual major equipment electricity use, industrial water use, individual major equipment natural gas use, raw materials flows, intermediate product flows, final product flows, outdoor temperature and humidity etc. The monitoring system was particularized for each BF and the total Capital Expenditures (CAPEX), OPEX and the expected energy savings obtained by implementing the aforementioned no cost EPIA's and operational improvement actions are presented in Table 6.

Table 6. Input data for energy monitoring system EPIA

\begin{tabular}{|c|c|c|c|}
\hline BF & CAPEX [EUR] & OPEX [EUR/year] & Energy savings [MWh/year] \\
\hline BF 1 & 245,000 & 5,000 & $2.406,48$ \\
\hline BF 2 & 212,000 & 3,500 & $1.698,93$ \\
\hline BF 3 & 240,000 & 5,500 & $2.115,69$ \\
\hline BF 4 & 208,000 & 3,500 & $1.614,60$ \\
\hline
\end{tabular}




\subsection{Renewable energy sources}

Considering that the environmental impact reduction is a main goal of the BF owner company, the use of renewable energy sources is an attractive mean of reaching the desired target of reducing the $\mathrm{CO}_{2}$ by $14 \%$ by the end of 2021 . As all the BFs are located in rural areas and occupy a significant surface, the implementation of photoelectric systems was proposed and analyzed from a technical point of view. By using a software simulation tool (RETScreen Expert) the Forecasted Electricity Productions were determined and are presented in Table 7. To mitigate the dusting of the PV modules, an automated washing system was also considered for each BF site (60 EUR/kWp).

Table 7. Photoelectric System simulation result

\begin{tabular}{|c|c|c|c|c|c|c|}
\hline Factory & $\begin{array}{c}\text { Available } \\
\text { Surface } \\
{\left[\mathrm{m}^{2}\right]}\end{array}$ & $\begin{array}{c}\text { Effective } \\
\text { PV System } \\
\text { area }\left[\mathrm{m}^{2}\right]\end{array}$ & $\begin{array}{c}\text { PV } \\
\text { System } \\
\text { Peak } \\
\text { Power } \\
{[\mathrm{kW}]} \\
\end{array}$ & $\begin{array}{c}\text { CAPEX } \\
\text { [EUR] }\end{array}$ & $\begin{array}{c}\text { OPEX } \\
\text { [EUR/year] }\end{array}$ & $\begin{array}{l}\text { Forecasted } \\
\text { Electricity } \\
\text { Production } \\
\text { [MWh/year] }\end{array}$ \\
\hline BF 1 & $14,123.69$ & $6,230.00$ & 988.40 & $707,694.40$ & $8,846.18$ & $1,464.67$ \\
\hline BF 2 & $12,596.58$ & $4,414.00$ & 600.25 & $429,779.00$ & $5,372.24$ & 810.38 \\
\hline BF 3 & $10,445.30$ & $4,414.00$ & 600.25 & $429,779.00$ & $5,372.24$ & 844.54 \\
\hline BF 4 & $9,347.48$ & $2,522.00$ & 400.05 & $286,435.80$ & $3,580.45$ & 534.22 \\
\hline
\end{tabular}

* determined by considering an average standard CAPEX of 656 EUR/kWp in Romania.

\subsection{Waste heat recovery}

All four BFs have an available waste heat source in the form of exhaust gases at a temperature of 140 Celsius Degrees. As per [17], the specific Investment Cost of a smallscale Organic Rankine Cycle (ORC) system which can use the available heat source is estimated at approximatively $2,500 \mathrm{EUR} / \mathrm{kW}$ with an installed power of the ORC system of $150 \mathrm{kWe}$.

Thus, the estimated CAPEX for the EPIA is 375,000 EUR. As [18] has shown, an ORC System has an annual operation time of approximatively 7,800 hours/year with an average OPEX of 7,500 EUR/year. As per the Romanian legislative framework [19], an analysis period of 12 years was considered.

\subsection{Global analysis results}

The potential energy savings and the potential environmental impact reduction of each EPIA is presented in Table 8.

Table 8. EPIA Analysis

\begin{tabular}{|c|c|c|c|}
\hline EPIA & Applicable to & $\begin{array}{c}\text { Potential Energy } \\
\text { Savings [MWh/year] }\end{array}$ & $\begin{array}{l}\text { Potential Environmental } \\
\text { Impact Reduction } \\
\text { [tons } \mathrm{CO}_{2} / \text { year] }\end{array}$ \\
\hline \multirow{4}{*}{$\begin{array}{l}\text { Advanced } \\
\text { Monitoring } \\
\text { System }\end{array}$} & BF 1 & $4,026.84$ & 813.42 \\
\hline & BF 2 & $2,842.88$ & 574.26 \\
\hline & BF 3 & $3,540.25$ & 715.13 \\
\hline & BF 4 & $2,701.76$ & 545.76 \\
\hline \multirow{4}{*}{$\begin{array}{l}\text { Photovoltaic } \\
\text { system }\end{array}$} & BF 1 & $1,464.67$ & 505.31 \\
\hline & BF 2 & 810.38 & 279.58 \\
\hline & BF 3 & 844.54 & 291.37 \\
\hline & BF 4 & 534.22 & 184.30 \\
\hline ORC system & $\mathrm{BF} 1, \mathrm{BF} 2, \mathrm{BF} 3, \mathrm{BF} 4$ & $1,170.00$ & 403.65 \\
\hline
\end{tabular}


It can thus be concluded that by implementing the analyzed EPIAs, the overall potential energy savings could amount to $1,844.32$ t.o.e./year, respectively $7.37 \%$ of the baseline energy use. The cumulated environmental impact reduction potential is 5,523.73 tons $\mathrm{CO} 2 /$ year, respectively $8.77 \%$ of the baseline environmental impact, as it can be observed from Table 9.

Table 9. The potential to reduce the environmental impact

\begin{tabular}{|c|c|c|}
\hline Factory & $\begin{array}{c}\text { Total Potential Equivalent Energy } \\
\text { Savings [t.o.e./year] }\end{array}$ & $\begin{array}{c}\text { Total Potential Environmental Impact } \\
\text { Reduction [tons } \mathbf{C O}_{2} \text { /year] }\end{array}$ \\
\hline BF 1 & 572.89 & $1,722.38$ \\
\hline BF 2 & 414.80 & $1,257.49$ \\
\hline BF 3 & 477.71 & $1,410.15$ \\
\hline BF 4 & 378.91 & $1,133.71$ \\
\hline
\end{tabular}

\section{Financial Analysis}

The main criterions used in the technic and economic analysis of the EPIAs were the Net Present Value - NPV (8), the Internal Rate of Return - IRR (9), the Simple Payback Period - SPP (10), determined by considering a variable annual net income and the Benefit - Cost Analysis - BCA (11).

$$
N P V=\sum_{t=1}^{t s t} \frac{I_{t}-C_{t}}{(1+a)^{t}}-I C[E U R]
$$

where $t_{t s t}$ is the analysis time-frame, in years, selected as per [19], $I_{t}$ is the yearly income in the $t^{\text {th }}$ year, in EUR/year, $C_{t}$ are the yearly expenditures in the $t^{\text {th }}$ year, in EUR/year, $a$ is the discount rate $-11.38 \%$ /year for this end-user and IC is the investment cost, in EUR.

$$
N P V=\sum_{t=1}^{t s t} \frac{I_{t}-C_{t}}{(1+I R R)^{t}}=0[E U R]
$$

where the CAPEX can be included in the yearly expenditures as a depreciation cost.

$$
\begin{gathered}
S P P=\frac{I C}{\frac{\sum_{i=1}^{t} I_{i}-C_{i}}{t}}[\text { years }] \\
B C A=\frac{I C}{N P V}[-]
\end{gathered}
$$

An average escalation rate for electricity prices of 5\%/year was also considered, as determined in [20]. The technic economic analysis results will be presented in Table 10.

Table 10. Financial Analysis

\begin{tabular}{|c|c|c|c|c|c|}
\hline EPIA & Applicable to & NPV [EUR] & IRR [\%] & SPP [years] & BCA [-] \\
\hline \multirow{2}{*}{$\begin{array}{c}\text { Advanced } \\
\text { Monitoring } \\
\text { System }\end{array}$} & BF 1 & 123,390 & $21 \%$ & 5.31 & 1.5 \\
\cline { 2 - 6 } & BF 2 & 53,182 & $16 \%$ & 6.15 & 1.25 \\
\cline { 2 - 6 } & BF 3 & 83,511 & $18 \%$ & 5.83 & 1.35 \\
\cline { 2 - 6 } & BF 4 & 42,996 & $15 \%$ & 6.32 & 1.21 \\
\hline \multirow{3}{*}{$\begin{array}{c}\text { Photovoltaic } \\
\text { system }\end{array}$} & BF 1 & $1,120,265$ & $26 \%$ & 5.35 & 2.58 \\
\cline { 2 - 6 } & BF 2 & 615,692 & $24 \%$ & 5.74 & 2.43 \\
\cline { 2 - 6 } & BF 3 & 661,285 & $25 \%$ & 5.56 & 2.54 \\
\cline { 2 - 6 } & BF 4 & 402,493 & $24 \%$ & 5.79 & 2.41 \\
\hline \multirow{2}{*}{ ORC system } & BF 1, BF 2, & 764,209 & $36 \%$ & 4.03 & 3.04 \\
\hline
\end{tabular}

It can be observed that all proposed EPIAs lead to attractive financial indicators. For BF 1 the most attractive EPIA is the installation of a photoelectric system. The difference 
between the economic viability of the PV system for the four BFs is mainly generated by the difference in the available rooftop surfaces and by the difference in solar potential. For all the other BFs the most attractive EPIA is the implementation of Organic Rankine Cycle electricity production system. It can also be observed that in all analyzed scenarios the SPP is less than or close to 5 years.

\section{Conclusions}

This paper demonstrated that the brick manufacturing industry, to achieve environmental sustainability, must be subjected to an in-depth analysis in order to properly identify specific EPIAs at process level. Even though, as proven in chapters 3 and 4, and shown in Table 11, the implementation of large scale, outside the process level, EPIAs can lead to a major EnPI and global EI improvement, the target set by the owner company cannot be reached in the desired timeframe.

As the carbon neutrality target implies the mitigation of all forms of $\mathrm{CO}_{2}$ equivalent emissions, even though the electricity used by the BFs already include the EUA costs, an increase in the overall energy performance of the analyzed BFs will lead to a global decrease in the Environmental Impact generated by the company (electricity and natural gas). The various analyzed EPIAs include both forms of energy and, as a result, the EI improvement is a global rather than a natural gas specific one.

Table 11. Centralized results

\begin{tabular}{|c|c|c|c|c|c|}
\hline Factory & $\begin{array}{c}\text { Obtainable } \\
\text { Energy } \\
\text { Intensity } \\
\text { [t.o.e./1,000 } \\
\text { EUR] }\end{array}$ & $\begin{array}{c}\text { EI } \\
\text { Reduction }\end{array}$ & $\begin{array}{c}\text { Obtainable } \\
\text { Environmental } \\
\text { Impact [tons } \\
\text { CO }_{\mathbf{2}} / \text { year] }\end{array}$ & $\begin{array}{c}\text { Environmental } \\
\text { Impact } \\
\text { Reduction }\end{array}$ & $\begin{array}{c}\text { Obtainable } \\
\text { NPV [EUR] }\end{array}$ \\
\hline BF 1 & 0.6132 & $7.32 \%$ & $18,177.23$ & $8.66 \%$ & $2,275,427$ \\
\hline BF 2 & 0.4678 & $7.77 \%$ & $12,043.93$ & $9.45 \%$ & 861,309 \\
\hline BF 3 & 0.5471 & $7.14 \%$ & $15,347.44$ & $8.41 \%$ & 984,436 \\
\hline BF 4 & 0.8939 & $7.35 \%$ & $11,918.33$ & $8.69 \%$ & $1,392,581$ \\
\hline
\end{tabular}

As it was shown in chapter 2, there are certain variable factors which cannot be optimized. One such factor is the quality of the clay used in the process. As each factory has its own clay quarry located in the vicinity of the factory, the optimization of this variable factor is improbable. The only mean of optimizing this factor could be to find a new clay quarry, with better properties. This could, in turn, lead to an increase in the overall energy use, as the raw material should have to be transported from the quarry to the production site with an additional fossil fuel use. Further research is required in order to develop a normalization methodology for properly quantifying the influence of the static and variable factors on the EnPIs, thus facilitating the optimization of this interdependency. All the proposed EPIAs are easily replicable to other building materials industries such as the cement, lime or reinforced steel industries as they all have the same characteristics regarding the occupied land (PV System available surface), energy uses (electricity and heat) and process type (linear, first in - first out).An additional technic and economic analysis of the viability of retrofitting the existing heat treatment ovens with dual fuel burners and increasing the mix of green hydrogen in the brick manufacturing processes must be conducted. In accordance with [21] the share of hydrogen in Europe's energy mix is expected to grow from less than $2 \%$ to $14 \%$. It is thus obvious that hydrogen will also play a key role in the transition towards environmental sustainability of the brick manufacturing industry sector. 


\section{References}

1. https://ec.europa.eu/growth/sectors/construction/observatory_en, accessed on 28.02.2021.

2. Eurostat, "Housing Statistics," 2020, https://ec.europa.eu/eurostat/statisticsexplained/.

3. Research and Markets, "Construction Materials - Global Market Trajectory \& Analytics," 2020.

4. The European Parliament, "Directive (EU) 2018/844 amending Directive 2010/31/EU on the energy performance of buildings and Directive 2012/27/EU on energy efficiency," 2018.

5. European Commission, "EU climate action and the European Green Deal," https://ec.europa.eu/clima/policies/eu-climate-action_en, 2019.

6. European Comission, https://ec.europa.eu/growth/sectors/construction_en, accessed on 12.03.2021.

7. Alaa Shakir, Ali Mohammed, "Manufacturing of Bricks in the Past, in the Present and in the Future: A state of the Art Review," International Journal of Advances in Applied Sciences, Vol. 2, No. 3, September 2013, pp. 145 156, ISSN: 2252-8814, 2013.

8. D. Sakthivel, R. Dharunkumarasamy, L. Karthikeyan, S. Praveen Kumar, B. Surya, "Experimental investigation on brick manufacturing by using sludge \& pulp production residue," International Research Journal of Engineering and Technology (IRJET), Volume: 06, Issue: 03, pp 266 - 274, ISSN: 2395-0072, 2019.

9. Jeorge J. Venta, P.Eng. "Life cycle analysis of brick and mortar products", the ATHENATM Sustainable Material Institute, Canada, Ottawa, 1998.

10. Michael Chusid, Steven H Miller, Julie Rapoport. "The building bricks of sustainability", The Construction Specifier, Vol. 1. Pp. 30-40, 2009.

11. Dachamir Hotza and Bianca Goulart de Oliveira Maia, "Environmental performance and energy assessment of fired-clay brick masonry," Eco-efficient Masonry Bricks and Blocks: Design, Properties and Durability, pp 447-459, DOI: 10.1016/B978-1-78242-3058.00020-6, 2014.

12. European Investment Bank, "EIB Project Carbon Footprint Methodologies: Methodologies for the Assessment of Project GHG Emissions and Emission Variations," (2020).

13. European Comission, https://ec.europa.eu/clima/policies/ets/revision_en\#tab-0-0, accessed on 12.03.2021

14. www.gobrick.com, accessed on 11.03.2021.

15. International Standardization Organization, "ISO 50001:2018 Energy Management Systems," 2018

16. Efficiency Valuation Organization, International Performance Measurement and Verification Protocol (IPMVP), https://evo-world.org/en/products-services-mainmenuen/protocols/ipmvp

17. Lorenzo Tocci, Tamas Pal, Ioannis Pesmazoglou and Benjamin FranchettiSmall, "Scale Organic Rankine Cycle (ORC):A Techno-Economic Review," Energies, 10, 413; doi:10.3390/en10040413, 2017

18. George Kosmadakis, Panagiotis Neofytou, "POTENTIAL AND COST EFFECTIVENESS OF A REVERSIBLE HIGH-TEMPERATURE HEAT PUMP/ORC UNIT FOR THE EXPLOITATION OF INDUSTRIAL WASTE HEAT," 5th International Seminar on ORC Power Systems, 2019

19. The Romanian Government, "Decision no. 2139/30.10.2004 for approving the normal period of use for capital goods," Official Gazette, Part I, No. 46/13.01.2005

20. Ioan-Sevastian Bitir-Istrate, Cristian Gheorghiu and Miruna Gheorghiu, "The Cost of Indecision in Energy Efficiency. A Cost of Opportunity Analysis for an Industrial 
Consumer," 55th International Scientific Conference on Information, Communication and Energy Systems and Technologies (ICEST), DOI: 10.1109/ICEST49890.2020.9232894, (2020)

21. European Commission, "A hydrogen strategy for a climate - neutral Europe," 2020 